Derleme / Review

\title{
Ağız ve Diş Sağlığı Hizmetlerine Erişimdeki Engeller
}

\section{Barriers to Access Dental Care Services}

\author{
Mehmet Özyurt $\mathrm{a}^{\mathrm{a}^{*}}$ \\ araştırma Görevlisi, Mardin Artuklu Üniversitesi, Sağlık Bilimleri Fakültesi, Sağlık Yönetimi Bölümü, ORCID: https://orcid.org/0000-0001-8115-3460 \\ "İletişimden sorumlu yazar, E-mail: ozyurtmehmet1@gmail.com
}

\section{ARTICLE INFO}

Article History:

Received 05.08.202

Received in revised form 22.10.2021

Accepted 28.10.202

Keywords:

Dental care services

Health services

Barriers to access services

\begin{abstract}
Health service is a fundamental right that states should provide to their communities. Oral and dental care services are also within the scope of health services. However, it is separated from health services at some points and this situation creates barriers in accessing services. The aim of this study is to identify the barriers and problems in accessing dental care services by reviewing the literature. For this purpose, the research was carried out by searching the database of Web of Science on 25.06.2021 and this brings up 18 articles containing the foloowing terms group "barrier OR problem OR lack" AND "access" AND "dental care" in the title of the articles, and 16 articles were included in the review. Most of the articles reviewed were conducted in the USA, the most frequently cited barriers; dentists' reluctant behaviour, the cost of services, and barriers to individuals with special service needs. As solution suggestions, governments should create health policies that minimize these barriers, being aware of the fact that there are sections in the society who experience barriers in accessing oral and dental health services, increasing health insurance coverage at least for disadvantaged individuals, planning the geographical distribution of service delivery institutions in a way that does not hinder access, providing dentists and dental care services. It can be suggested that oral and dental health professionals should be given courses/trainings that will include individuals with special service needs, how to approach them and how to treat them.
\end{abstract}

(c) 2021 Mardin Artuklu University. All rights reserved.

\section{MAKALE BİLGILERI}

Makale Geçmişi:

Geliş Tarihi: 05.08.2021

Revizyon Tarihi: 22.10 .2021

Kabul Tarihi: 28.10 .2021

\section{Anahtar Kelimeler:}

Ağız diş sağlığ

Sağlık hizmetleri

Hizmetlere erişimdeki engeller

\section{ÖZET}

Sağlık hizmetleri devletlerin toplumlarına sunması gereken temel bir haktır. Ağız-diş sağlı̆ğ hizmetleri de sağlık hizmetlerinin kapsamındadır. Ancak bazı noktalarda sağlık hizmetlerinden ayrıșmıș olduğu (sigorta kapsamları, kamunun hizmetlerde ağırlı̆g vb.) ve bu durumun hizmetlere erișimde engeller olușturduğu görülmektedir. Ülkelerin, sağlık hizmetlerine ve özellikle ağız-diş sağlığı hizmetlerine erişiminin toplumun tüm kesimlerine herhangi bir engelle karşılaşmayacakları şekilde sunabilmesi önemlidir. Bu çalışmanın amacı ağız ve diş sağlı̆̆ı hizmetlerine erişimdeki engellerin ve problemlerin literatür taraması yoluyla belirlenmesidir. Bu amaçla araştırmanın evrenini, Web of Science veri tabanında 25.06.2021 tarihinde yapılan tarama ile, makale başlığında "barrier OR problem OR lack" AND "access" AND "dental care" kelime gruplarının yer aldı̆̆ 18 makale olusturmuștur. İki makalenin tam metnine ulaşılamadığından 16 makale incelemeye alınmıştır. İncelenen makalelerin çoğunun Amerika Birleşik Devletleri'nde (ABD) yapıldığı, en sık belirtilen engellerin; diş hekimlerinin isteksiz davranışları, hizmetlerin maliyeti ve özel hizmet ihtiyacı olan bireylerle ilgili engeller olduğu görülmüștür. Daha sonra sırasıyla; sigorta ile ilgili engeller, ulașım, hizmet sağlayıcı bulamama, uzun bekleme süreleri, kalitesiz hizmet algısı, gelir düşüklüğü, dental kaygı, ihtiyacın algılanamaması, iletişim problemleri, ırksal ayrımcılıklar, geçmiş deneyimler ve sağlık personelinin eksikliği olduğu belirlenmiştir. Çözüm önerileri olarak, toplumda ağız-diş sağlığı hizmetlerine erişimde engeller yaşayan kesimler olduğunun bilincinde olarak hükümetlerin bu engelleri en aza indirecek sağlık politikaları olușturmaları, sağlık sigorta kapsamlarının en azından dezavantajlı bireyler için yükseltilmesi, hizmet sunan kurumların coğrafi dağılımının erișimi engellemeyecek șekilde planlanmaș, diș hekimlerine ve ağız-diș sağlığı sağlık profesyonellerine özel hizmet gereksinimi olan bireyler ve bunlara nasıl yaklaşılması, nasıl tedavi verilmesini içerecek kurs/eğitimlerin verilmesi önerilebilir.

(c) 2021 Mardin Artuklu Üniversitesi. Tüm hakları saklıdır.

\section{Giriş}

Literatürde düzenli olarak diş hekimi ziyaretleri ile ilgili bazı kesimler bunun sadece bir diş hekimliği hegemonyası olduğunu savunurken, bazı kesimler tartışmasız bunun genel sağlı davranışının ayrılmaz bir parçası olarak görmektedirler. Her ne şekilde algılanıyor olursa olsun bazı kişilerin düzenli olarak diş hekimine gidemediği ve bu hizmetlere erişemediği durumlar vardır. Bu kişiler; korunmasız gruplardaki insanlar, yaşlılar, işsizler, evsizler, kırsalda yaşayanlar, ekonomik durumu kötü 
olanlar, özel sağlık hizmeti gereksinimi olan engelli bireyler ve sığınmacılar olarak belirtilebilir (1-4).

Freeman (1999), 1980'ler ve 1990'larda yapılan çalışmalarda ağız-diş sağlığı hizmetlerine erişimdeki engellerin daha çok fiziksel engeller olarak ele alındığını belirtmiştir (bazı hastalar için merdiven engeli, bazı diş hekimleri için hizmetlerin eşitsizliğine ilişkin fiziksel engeller, toplum için de sağlik finansmanı problemleri ele alınmıştır). Ancak FDI (The Federation Dentaire Internationale) bu konuda üç ayrı engel kategorisinin ele alınmasını önerir. Birinci engel kategorisi birey ile ilgili olup "algılanan ihtiyaç, endişe ve korku, finansal konular ve erişim eksikliği” kavramlarını içerir. İkincisi, diş hekimliği mesleği ile ilgilidir ve "uygun olmayan iş gücü kaynağı, eşit olmayan coğrafi dağılım, değişen ihtiyaç ve taleplere uygun olmayan eğitim, hastanın tutum ve ihtiyaçlarına yetersiz duyarlılık" konularını içerir. Üçüncüsü de toplum ile ilgilidir ve "sağlığa elverişli tutumlar için toplumun yetersiz desteği, yetersiz ağız-diş sağlığı hizmet kurumu, yetersiz ağız-diş sağlığ insan gücü planlaması ve araştırmalar için yetersiz destek” engellerini içerir (1)

Literatürde yapılmış derleme çalışmalarına bakıldığında, ElYousfi ve ark. (2019), Goode ve ark. (2018), Hadgkiss ve ark. (2014) ve Rosa ve ark.'nın, (2020) çalışmaları dikkat çekmektedir.

El-Yousfi ve ark. (2019), tarafindan hassas gruplardaki insanların ağız ve diş sağlığı hizmetlerine erişim engelleri ile ilgili literatürün incelenmesi amacıyla yapılan çalışmada korunmasız gruplardaki insanların, genel nüfusa kıyasla daha yüksek düzeyde tedavi edilmemiş diş hastalıklarına sahip olduklarını, ancak genellikle bakıma erişimde engeller yaşadıkları belirlenmiştir Medline veri tabanı kullanılarak 2007-2017 yılları arasında yapılmış çalışmaları kapsayan bu çalışmada toplam 308 makale incelenmiş olup tüm hassas grupların karşılaştıkları ortak engeller; satın alınabilirliğin olmaması, bakıma erişimdeki zorluklar, uygun bakımın bulunmaması ve özel hizmetler için kamu finansmanının olmaması olarak belirlenmiştir. Potansiyel çözümler için hastalara ve sağlik hizmet sunucularına, ağız-diş sağlı̆̆ 1 ve diş hekimliği hizmetlerine erişim hakkında eğitim ve bilgi sağlanması, diş hekimlerinin hassas grupların bakımı konusunda eğitilmesini ve hassas grupların ihtiyaçları için diş hekimliği hizmetlerinin kamu tarafindan finanse edilmesini önermişlerdir (2).

Goode ve ark. (2018) evsiz insanların ağı-diş sağlığ hizmetlerine erişimindeki engelleri belirlemeyi amaçladıkları çalışmalarında sonuç olarak 5 ana tema (evsizlerin ağız-diş sağlığı hizmetlerine nasıl eriştiği, hizmet alımını etkileyen faktörler, hizmete erişimi iyileştirmek için kullanılan stratejiler, diş hekimi olmayan personelin ağız-diş sağlığı hizmetine etkisi ve evsiz insanlara hizmet sunmanın zorlukları) belirlemişlerdir. Ağız-diş sağlığı hizmetlerini, diş hekimlerinden, diş hekimliği öğrencilerinden, diş hijyenistlerinden, doktorlardan ve acil servislerden aldığı tespit edilmiş, diş hekimi ziyaretlerinin genellikle ağız-diş sağlı̆̆ında bir problem çıkması üzerine yapıldığını belirtmişlerdir. Evsizler genellikle ağız-diş sağlığı problemlerini reçeteli veya yasadışı uyuşturucular, alkol veya kendi kendine tedavi kullanarak kendi başlarına yönetmektedir. Evsizlerin ağız-diş probleminde acil servise başvuruları, düşük gelirli insanların başvurularından 2 kat fazladır ve acile başvuran evsizlerin en az yarısı birden fazla kez acil servisi ziyaret etmek zorunda kalmıştır. Engeller ise; ödeme yapamama en çok belirtilen engel olmuştur. ABD'de evsiz yetişkinlerin üçte birinden fazlası ağız-diş sağlığı hizmetlerini nerede bulacağını bilmiyordu. Diş hekimliği hizmetlerinin reklamı yetersizdi, ancak devlet tarafindan finanse edilen hizmet mevcut olduğunda ve kliniğin yeri bilindiğinde bile, evsiz insanlar tarafından yetersiz bir hizmet alımı vardı. Özellikle uyuşturucu ve alkolün kötüye kullanıldığı dönemlerde, evsiz insanlar için ağız-diş sağlığı düşük bir öncelik olabilir. Evsiz insanların kapsamlı diş bakımı yerine acil durum arama olasılığı daha yüksek çıkmıştır (3).

Hadgkiss ve ark. (2014), çalışmalarında sığınmacıların fiziksel durumu, sağlık hizmetlerine erişimlerini ve karşılaştıkları engelleri ele almışlardır. Sığınmacıların tarama, sağlık eğitimi, koruyucu sağlık hizmetleri, ağız diş sağ lığı hizmetlerini kullanma oranları çok düşük olarak saptanmıştır (4).

Rosa ve ark., (2020) engellilerin diş hekimliği hizmetlerine erişiminin önündeki engelleri araştırdıkları sistematik derlemede, engelli bireylerin diğerlerine göre daha fazla ağız-diş sağlığı sorunu yaşadıklarını belirtmişlerdir. Diş hekimliği hizmetlerinin önündeki engelleri, diş hekiminin bakış açısına göre, ebeveyn/veli veya engellilerin algısına göre fiziksel ve fiziksel olmayan olarak ayırmışlardır. Ortaya çıkan engeller arasında diş hekiminin engelli insanlara yardım etmek için hazırlıklı olmaması, diş muayenehanelerine erişimimeki yapısal sorunlar, iletişim güçlükleri ve engelli kişinin diş tedavisi ihtiyacına ilişkin farkındalık eksikliği olarak belirtilmiştir (5).

Literatürdeki derleme çalışmalarına bakıldığında, genel olarak bir grubun perspektifinden o grubun ağız-diş sağlığı hizmetlerine erişimi ve karşılaştığ engeller çalışılmıştır. Bu derleme çalışması farklı gruplar ile yapılmış çalışmalardan elde edilen sonuçları bütünsel olarak ele almayı amaçlayarak yazılmıştır. 


\section{Yöntem}

Derleme çalışması olarak yazılan bu çalışmanın evrenini Web of Science veri tabanlarından 25.06.2021 tarihinde yapılan tarama ile, makale başlı̆̆ında "barrier/problem", "access", "dental care" kelime gruplarının yer aldığı 18 makale oluşturmuştur. İki makalenin tam metnine ulaşılamadığından 16 makale incelemeye alınmıştır.

Tablo 1 - Çalışma Kapsamı

\begin{tabular}{|c|c|c|c|}
\hline Veri Tabanı & Anahtar Kelimeler & Tarama & Çalışmaya \\
\hline Web of Science & $\begin{array}{c}\text { Title: "barrier OR } \\
\text { problem OR lack" } \\
\text { AND "access" AND } \\
\text { "dental care" }\end{array}$ & 18 & 16 \\
\hline
\end{tabular}

Makalelerin diş hekimliği hizmetlerine erişimin önündeki engeller ve problemlerin belirlenmesine hangi yöntemleri kullandıkları, çalışmaların hangi ülkelerde yapıldığı, ulaşılan sonuçlarda ülkeler arasında bir farklılık olup olmadığı ve sonuçların genelleştirilip genelleştirilemeyeceği konuları üzerinde durulmuştur. Makaleler yayın yılına göre eskiden yeniye doğru incelenmiştir.

\section{Bulgular}

Grafik 1 yıllara göre yayın sayısını vermektedir. En fazla yayının Freeman'ın yazdığı 3 makale ile 1999 yılında yazılmış olduğu görülmektedir. Bazı yıllar hiçbir çalışma yapılmadığı son yıllarda ise 2'şer makale yazıldığ görülmektedir (2019 ve 2020).

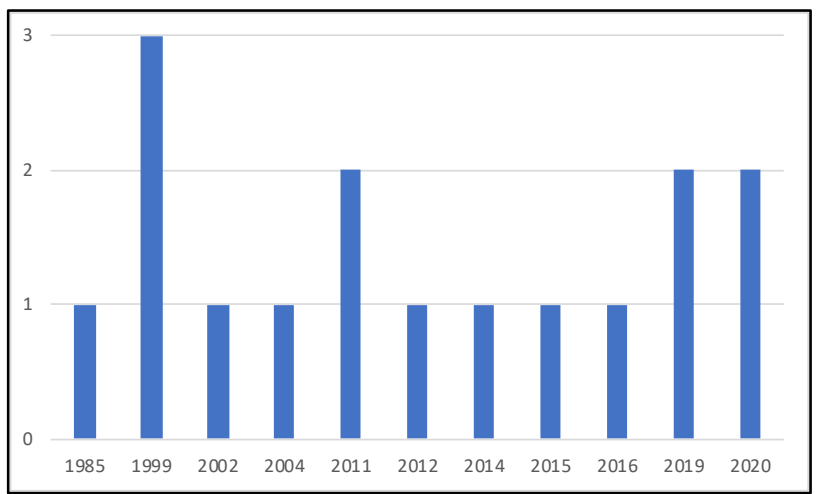

Grafik 1 - Yıllara Göre Yayın Sayıs1

O’Donnel (1985), Hong Kong'daki Engelliler: Diş Bakımına Erişim Sorunları başlıklı makalesinde dönemin Hong Konh'unda hem çok zengin ailelerin hem de çok yoksul ailelerin yaşamakta olduğunu belirtir. Bazı ailelerin (6-7 kişiden oluşan) tek bir odada yaşadığını belirten yazar engelli bireylerin durumunu ortaya koymak için bu çalışmayı yapmıştır. 1981'de yapılan nüfus sayımına göre Hong Kong'da yaşayan 41.000 fiziksel ve zihinsel özürlü birey olduğu ortaya çıkmıştır. Engelli bireylerin halka açık yerlerde görülmesi çevresel ve kültürel nedenlerden dolayı nadirdir. Hong Kong'un çok kalabalık bir nüfusa sahip olduğu ve sokaklarının dik adımlarla birbirine bağlanan engebeli bir yer olduğunu belirten yazar, yürüyemeyen engelli çocukların tamamen ebeveyne bağımlı olduğunu ve büyüdükçe de ebeveyn için fiziksel olarak taşınmanın imkânsız hale geldiğini yazmıştır. Kültürün de bir etkisi olarak bir ailede engelli bir birey doğduğunda bu aile tarafından bir rezalet, geçmişte yapılan bazı yanlışların bir cezası gibi görülmektedir. Bu yüzden evde bile komşuların görmeyeceği bir yerde saklanma durumları vardır ki toplum tarafından aile kötü damgalanmasın. Ancak eğitimi yüksek aileler devlet destekli eğitim kurumlarına çocuklarını göndermekte, sosyal hayata entegre olmalarını sağlamaktadır (6). Hong Kong'da ücretsiz kapsamlı bir sağlık sistemi olmadığını, diş hekimliği hizmetlerinin devlet destekli 4 yaşına kadar indirimli verildiği ancak 4 yaşından sonra tamamen cepten ödeme ile hizmet alındığını belirten yazar, diş tedavisini ancak ve ancak genel anestezi altında alabilecek olan engelli bireylerin en fazla etkilenen grup olduğunu belirtmiştir. Özet olarak Hong Kong'da engelli bireyler için diş hekimliği hizmetlerinin önünde sıkışık barınma koşulları, aşırı kalabalık, engebeli yollar, kapsayıcı sağlık sigortasının olmayışı, aynı zamanda diş hekimlerinin de engelli bireyleri tedavi etmede isteksiz olmaları (bunun için detaylı eğitim almadıkları korkusu nedeniyle) gibi bariyerlerin olduğunu belirtmiştir (6).

Freeman, (1999), ağız diş sağlı̆ğ hizmetlerine erişmenin ve bu hizmetleri kabul edip katılmanın önündeki engelleri araştırdığı makalesinde, hastaların diş sağlığı hizmetleri kullanımını etkileyen psiko-sosyal faktörleri ve işler ters gittiğinde diş hekiminin nelere yardımcı olabileceğini incelemiştir. Kişilerin diş sağlığına erişme ve/veya diş hekiminin tavsiyelerine uyup diş sağlığı bakımına uyma konusundaki duygu, inanç ve tutumları, kişilerin büyüdüğü dönemle, ailelerinin diş sağlığına ne kadar önem verdiği ile veya kişilerin daha önce yaşamış oldukları kötü ağız diş sağılığı bakımı deneyimleri ile ilişki olabildiğini belirten yazar, bu gibi durumların diş sağlığı tutum ve davranışlarının psiko-sosyal belirleyicileri olduğunu, bunların kişinin ağız diş sağlığ1 hizmetlerini kabul etme ve bunlara erişmenin önünde engeller oluşturabileceğini belirtir. Diğer yandan ağız-diş sağlığına erişen bireylerde bu kez tedaviye dahil olma/kabul etme konusunda da dirençler (randevuyu iptal etmek, planlanan 
ameliyata bahaneler bularak gitmemek vb.) yaşanabilmektedir. Çocuklardaki dirençler çocuğun gelişim evresi ile ilgilidir. Yine ergenler sağlık profesyonelini kendi istediğini bireye dayatan başka bir ebeveyn figürü olarak gördükleri için ağız-diş sağlığ hizmetlerinden veya planlanan randevulardan kaçabilmektedirler. Hastaların davranışlarını ve eylemlerini gözlemlemek, diş hekimine bunların engel oluşturmasının önüne geçmede bir firsat tanıyabilir. Engelleri genel olarak psiko-sosyal karakterde olanlar ve hekim-hasta ilişkisi içinde olanlar olarak 2'ye ayıran yazar diş sağlığı profesyonellerinin hastaların bu engellerini anlamalarını ve tedaviye uyum sağlamaları için hastalara yardımcı olmaları gerektiğini önermektedir (1).

Freeman (1999b), yukarıdaki önceki çalışmasının devamı olarak ağız-diş sağlığı hizmetlerine erişimde engeller: hasta faktörleri başlıklı bu çalışmasında, psiko-sosyal faktörler olarak dental kayg1 durumları (dental fobi), finansal maliyetler, ihtiyacın algılanması ve erişim eksikliği olarak 4 faktör belirtmiş ve bunların detaylarını ele almıştır. Diş sağlığı profesyonellerinin özel psikolojik ihtiyaçları olan hastaları belirleyebilmeleri gerektiği, bunun için kısa dental anksiyete ölçeği gibi formlar olduğunu, böylece diş hekiminin diş kaygısı olan veya diş fobisi olan hastanın diş sağlığına erişmesine yardımcı olacak bir konumu olacağını belirtmiştir. Finansal maliyetler konusunda Dünya çapında yapılan çalışmalar insanların ağız-diş bakımına erişimde gelirlerinin doğrudan etkili olduğunu göstermiştir. Ayrıca tedavileri desteklenen bireyler için kullanılan malzeme hastayı memnun etmeyecek en düşük kalitede olmaktadır. Düşük gelirli ailelerde ihtiyaçlarının yanında diş hekimliği hizmetleri lüks olarak hissedilmektedir. Bireylerin tedavi ihtiyacı algılamaları önceki dental deneyimi ve yaşam tarzıyla ilişkilidir. Hissedilen tedavi ihtiyacının bakım talebine dönüşme itici gücü psiko-sosyal faktörlerin bir kombinasyonuna dayanır. Erişim eksikliği ise ağız-diş sağlığı hizmetlerine erișimdeki fiziksel yönlere ve iletişim - dil ile ilgili sorunlara atıfta bulunur. Dil ve iletişim sorunları, diş tedavisi ile ilgili endişeleri artıran yanlış anlamalara yol açabilir. Karşılaşılan fiziksel zorluklar erișim eksikliği, bekleme alanlarına, tuvaletlere tekerlekli sandalye ile erişim, ulaşım sorunları ve toplu taşımaya bağımlılık anlamına gelir. Erişim eksikliği, özellikle özel ağız-diş sağlı̆̆ bakımı ihtiyaçları olan kişileri etkiler. Yaşlı insanlar, fiziksel veya duyusal engelleri olan ve öğrenme güçlüğü çekenler ağız-diş sağlığı hizmetlerine erişimde sorunlar yaşayabilirler (7).

Freeman (1999c), bu çalışmasında da ağız-diş sağlığı hizmetlerine erişimde engelleri sağlık profesyonelleri açısından incelemiştir. Zamanla ilgili baskılar, korkan hastalar, yüksek vaka yükleri, finansal endişeler, personel ile ilgili sorunlar, ekipman arızaları, kusurlu malzemeler, kötü çalışma koşulları ve işin rutin ve sıkıcı doğası gereği diş hekimliğinin en stresli sağlık meslek grubu olduğu belirtilir. Bunlara ek olarak diş hekimliği genel pratisyen diş hekimliğinin geleceği ile ilgili endişeleri, agresif ve düşmanca hastalar, çapraz enfeksiyon riskine ilişkin endişeler ve dava edilmeye ilişkin korkuları içerir. Tüm bunlar diş hekiminin işle ilgisini azaltarak, hastalarına erişilebilir sağlık hizmeti sunmayı engeller. Bu durumdaki diş hekimleri dental kaygısı olan hastasına bu kaygıyı yenmesinde yardım edemeyecektir. Finansal açıdan da işletme maliyetleri ile ilgili sorunlar erişilebilirliği kötü etkilemektedir. Hedeflenen gelirlere ulaşmak ile erişilebilir diş hekimliği hizmetleri sunmak arasındaki ilişki, özel ihtiyaçları olan hastalarla ilgili muayenehane politikasını etkilemektedir. $\mathrm{Bu}$ hizmetleri sadece maliyetine katlanabilecek hastalara sunmaktadırlar, dolayısı ile bu etken de erişilebilirlik önünde bir engeldir. Sağlık personelinin coğrafi dağılımının eşitsizliği, değişen ihtiyaç ve taleplere yanıt verebilecek bir eğitim sistemin olmayışı, sağlık insan kaynağının yetersiz olması erişilebilirliğin önündeki diğer engellerdir (8).

Mofidi ve ark. (2002) Medicaid Sigortalı çocukların diş sağlığı hizmetlerine erişimdeki sorunlarını ele almışlardır. Medicaid'e kayıtlı her 5 çocuktan l'inden azı, belirli bir yılda önleyici hizmetlerden yararlanmaktadır. Daha da kötüsü, daha az sayıda Medicaid sigortalı çocuk, ilk önleyici ziyaretin ötesinde kapsamlı bir diş sağlığı hizmeti almakta. Anaokuluna kaydolan çocukların $\% 25$ 'inde tedavi edilmemiş diş çürüğüne rastlanmaktadır ve bu çocukların çoğu gelir düzeyi düşük ailelerden gelmekte (Medicaid'e uygun aileler). Çalışmalarında odak grup görüşmesi yöntemi ile verileri toplamışlardır. Örneklemi, en az 1 yıldır Medicaid'e üye ailelerden ve en son ne zaman çocuklarını Medicaid sigortasını kullanarak diş hekimine götürdükleri ve hangi engellerle karşılaştığını belirtebilecek, 4 farklı etnik grubu (Beyaz, Afrika kökenli Amerikalı, Latin ve Amerikan Kızılderili) temsil edebilecek örneklem seçmişlerdir. 77 katılımcı ile 11 odak grup oluşturdukları çalışmalarında grupların dördü Afrikalı Amerikalı (25 katılımc1), 3 Amerikan Kızılderili (21 katılımcı), 3 Latin (23 katılımcı) ve 1 grup da Beyazdı (8 katılımcı). Diş sağlı̆̆ hizmeti almanın önündeki engellerle ilgili üç ana tema belirlemişlerdir: Algılanan Engeller, Irksal/Etniksel Engeller, Sonuçlar. Algılanan engeller için, 2 ana kategori ortaya çıkmıştır, birincisi erişim ile ilgili engeller (hizmet sağlayıcı bulamama, randevu alamama, uygunsuz ve güvenli olmayan ulaşım, çok fazla bekleme süresi, diş hekimleri ile negatif etkileşim, Medicaid nedeniyle kötü ayrımcılık) ikincisi de deneyimin kalitesi ile ilgili 
algılanan engeller. Irksal/Etniksel Engeller için; Dil problemleri, ırksal ayrımcılıktır (en çok etkilenen grup Afrika kökenli Amerikalılardır). Sonuçlar için, çocukların okul günü kayıpları, aileler önüne koyulan sayısız engelden dolayı ailelerin çocuklarını diş hekimine götürmekten vazgeçmeleri gibi problemler belirtilmiştir (9).

Guay (2004) Amerikalıların artan ağız-diş sağlı̆̆ı seviyesinin tadını çıkardıklarını ancak ağız-diş sağlığı hizmetlerinde yapılan iyileştirmelerin nüfusun geneli için eşit bir şekilde deneyimlenmediğini, yoksulların, yaşlıların, bazı azınlıkların ağız-diş sağlığı hizmetlerine yeterli erişime sahip olmadıklarını belirtmiştir. 1983 ve 1998 yılları arasında Amerikalıların en az bir defa diş hekimini ziyaret etme oranı $\% 10,5$ 'ten $\% 65,5$ 'e yükselmiştir. Daha önce hiç diş hekimine gitmeyen çocuklar artık diş hekimine gitmeye başlamış, çürük diş ve kayıp diş sayısında azalma olmuştur. Ne yazık ki bu iyileştirmelerden toplumun tamamı faydalanamamıştır. Bazı gruplar (düşük gelirli yaş ırk ve etnik köken ile tanımlanan) ağız-diş sağlığındaki bu iyileştirmelere katılamamıştır. Bunda en büyük engellerle karşılaşanlar, yoksullar, kırsalda yaşayanlar, hareket kısıtlılı̆̆ olan kişiler, kültürel olarak izole edilmiş kişiler, işsizler, sigortasız olanlar, özel ihtiyaçları olan kişilerdir. Bunun düzeltilebilmesi için yapılacak politikaların başarıya ulaşması için; ağız-diş sağlığı sunumu, sağlık işgücü ve ekonomik çevreyi düşünerek oluşturulmalıdır. Tek bir alanda yapılan düzeltme veya çözümler geçici olacaklardır (10).

Schrimshaw ve ark. (2011), NewYork Harlem'de Afrika kökenli Amerikalı yetişkinlerin ağız-diş sağlığı hizmetlerine erişiminde sigorta ile ilgili engelleri araştırdıkları çalışmalarında, 118 Afroamerikalı ile yaptıkları görüşmelerde, katılımcıların çoğunun (\%21 özel, \%50 Medicaid) sigortalı olduğunu bildirmelerine rağmen, ağız-diş sağlı̆̆ hizmetlerine erişimde bildirdikleri engeller; teminat eksikliği, sigortasını kabul eden bir diş hekimi bulamama, kapsamın yürürlüğe girmesini beklemek, sigortasız veya eksik sigortası olanların kalitesiz hizmet aldığı algısıdır (11). Bertolami (2011), Amerika'da ağız-diş sağlı̆̆ı hizmetlerine erişimde önemli bir sorun olduğunu, ağız-diş hastalıkları yüzünden ölen çocukların olduğunu belirtmiştir. Diş tedavi fiyatlarının 1947'ye göre 3 kat, 1980'e göre 2 kat arttığını belirten yazar, diş hekimlerinin sayısındaki artışın nüfus artış hızından az olduğunu, diş terapisti eğitimi ve hizmet vermelerinin nasıl olabileceğini de tartışmış, diş terapistlerinin başlangıçta diş hekimlerinin yanında çalışacağı, sonrasında kendi kliniklerini kurmayacağı ve diş hekimlerine rakip olmayacakları, diş terapisti ve diş hekimi tarafından verilen hizmetlerde bir fark olmayacağ 1 şartlarını yazmıştır. Ancak burada tartışılması gereken konunun diş terapistlerinin bu hizmetlere erişimi iyileştirip iyileştiremeyeceğidir. Eğer iyileştiremeyecekse tüm girişimin boşa gideceğini belirtmiş̧tir (12).

Kalsi ve ark. (2011) kalıtsal kanama bozukluğu olan hastalar için birinci basamak ağız-diş sağlığ hizmetlerine erişim başlıklı makalelerinde, Doğu Londra bölgesindeki kalitsal kanama bozukluğu olan hastaların yaşadığı ve algıladıkları engelleri vurgulamayı amaçlamışlardır. 105 hasta ile bu hastaları tedavi eden 50 diş hekimine anket uygulamışlar, 105 hastadan 71'i (\%68) geçen 1 yıl içerisinde en az 1 defa diş hekimini ziyaret etmiştir. Diş hekimini ziyaret etmeyenlerin bildirdiği en büyük engel, yerel bir diş hekimine ulaşamamadır. 21 hasta hastalıkları nedeniyle diş hekimleri tarafından reddedildiğini belirtmiştir. 18 hasta geçmiş deneyimlerden dolayı diş hekimini tekrar ziyaret etme konusunda tereddüt göstermektedir. Ayrıca 105 hastanın 47'si kanama eğilimlerini de dikkate alarak bütçelerinin kendilerine yetmeyeceğini belirtmişlerdir. Diş hekimlerine uygulanan anket sonuçlarında ise 24 diş hekiminin (\%48) daha önce kanama hastalığı olan bir hastayı tedavi ettiği, 4 diş hekimi kalıtsal kanama hastalarını tedavi sırasında endişeli olacaklarından hastayı reddetmişlerdir. Diş hekimlerinin \%40’1 bu tür hastaları tedavi ederken kendilerinden emin değillerdir. Sağlık Bakanlığının bu tür hastalara tedavi verirken dikkat edileceklerle ilgili kursuna diş hekimlerinin \%92'si olumlu bakmıştır. Diş hekimlerinin \%90'1 hasta ile aralarında hemofili ve diş hekimliği uygulamalarının bilgilendirmesini içeren bir onam ile kendilerini daha güvende hissedecekleri ve hastaları ile daha iyi ilgilenebileceklerine katılmışlardır (13).

Thompson ve ark. (2013), Kanada'da maliyetin ağı-diş sağlığı hizmetlerine erișimde engel oluşunu, 5586 katılımcıdan elde edilen anket verisi üzerinden incelemişlerdir. Ankete katılanların yaklaşı yüzde 17,3'ü bir önceki y1l içinde maliyet nedeniyle bir diş hekiminden kaçınmıştı ve yüzde 16,5'i maliyet nedeniyle önerilen diş tedavisini reddetti. Düzeltilmiş tahminler, daha düşük gelirli ve diş sigortası olmayan katılımcıların, maliyet nedeniyle diş hekimlerinden uzak durma olasılıklarının dört kat ve maliyet nedeniyle önerilen diş tedavilerini reddetme olasıllklarının yaklaşık iki buçuk kat daha fazla olduğu sonuçlarına ulaşmışlardır (14).

Williams ve ark. (2015) Oakland'da 140bin özel ihtiyaçları olan hasta olduğunu buna karşıllk sadece 36 diş hekimi olduğunu belirten yazarlar diş hekimliği hizmetlerine erişimdeki engelleri belirlemek için, 3-26 yaşları arasındaki 117 kişiyle anket çalışması yapmışlardır. En zor engelin, özel ihtiyaçları olan 
kişilerin kendilerini tedavi etmeye istekli diş hekimi bulamamalarıdır. Ankete katılanların. \%20'sinin diş hekimi olmadığını, düşük gelir ile diş erişimi arasında da bir ilişki olduğunu tespit etmişlerdir. Diğer engeller, bekleme süreleri, mesafe ve ulaşımdır. Sonuç olarak özel bakım ihtiyacı olan bireyleri tedavi edebilecek ve bu konuda istekli diş hekimlerinin sayısının artırılması, buna özel eğitim verilmesi gerekmektedir. Oluşturulacak bir veri tabanı, ebeveynlerin, tıp uzmanlarının özel ihtiyaçları olan hastayı tedavi edebilecek diş hekimi bulmalarında yardımcı olacaktır (15).

Gerreth ve Borysewicz-Lewicka, (2016) zihinsel engelli özel bakım okullarındaki çocukların ağız-diş sağlığı hizmetlerine erişimlerini ebeveynlerinin görüşüne göre değerlendirdikleri çalışmalarında Poznan'daki (Polonya) sekiz özel bakım okulundan 264 ebeveyn arasında bir anket çalışması yapmışlardır. Kapalı uçlu sorular, çocukların diş bakımına erişimdeki engelleri ve ebeveynlerin çocuklarının diş bakımından duydukları memnuniyetle ilgiliydi. Ebeveynlerin yalnızca \%31,8'i diş bakımına erişimde herhangi bir sorun yaşamamıştır ve diş sağlığı hizmeti almanın önündeki en yaygın engel, ziyaret için uzun bekleme süresi olarak belirtilmiştir $(\% 36,7)$. En yaygın olarak, çocuklar diş cerrahisi koşullarında tedavi edilmiş $(\% 90,1)$, katılımcıların sadece \%42,1'i çocuklarının diş bakımından memnun kaldığını belirtmiştir. Engelli çocukların diş sağlı̆̆ hizmetlerine erişiminin iyileştirilmesine ihtiyaç olduğunu ortaya koyan yazarlar; engelli çocukların diş tedavisinin yanı sıra profilaksiye erişimini iyileştirecek özel bakım okullarında uzman diş klinikleri kurmak faydalı görünmektedir demişlerdir (16).

Higuera ve Prada (2016) orta gelirli bir ülke bağlamında (Kolombiya) sigortanın ağız-diş sağlığı hizmetlerini kullanımını nasıl etkilediğini ortaya koymayı amaçlayan yazarlar, farklı sigorta türlerine sahip olan ve hiç sigortası olmayanların diş hekimi ziyaretlerini ve yaptıkları toplam harcamaları karşılaştıran yazarlar, herhangi bir sağlik sigortasına sahip olan bireylerin ağız-diş sağlığı hizmetlerini kullanamama riskleri daha düşüktür. Sonuç olarak maliyet paylaşımının Kolombiya'da iyi planlandığını ve diş hekimine erişimde bir engel oluşturmadığını belirtmişlerdir (17).

Hamasha ve ark. (2019), Suudi Arabistan'ın yaşlı nüfusu arasında diş hekimliği hizmetlerine erişim ve kullanımla ilgili engelleri değerlendirmeyi amaçladıkları çalışmalarında tüm huzurevinde yaşayanlar $(n=73)$ dahil olmak üzere çeşitli yaşlı toplanma yerlerinden toplanan 350 yaşlıdan sistematik rastgele bir örneklem alınmış. Veriler, diş hekimliği hizmetlerine erişim ve diş hekimliği hizmetlerine yönelik sosyodemografik, davranışsal, tıbbi ve finansal engellerle ilgili yüz yüze yapılandırılmış görüşmeler yoluyla toplanmıştır. Yaşlıların yaklaşık sadece \%37'sinin diş hekimliği hizmetlerine uygun erişimi ve kullanımı olduğunu, diş hekimliği hizmetlerine uygun erişim ve kullanım ile ilişkili önemli değişkenler diş sağlığı sigortasının olması, uygun fiyatlar ve düzenli diş firçalama, yüksek öğrenim ve evli olmak kriterleri belirlenmiştir. Sonuç olarak algılanan ihtiyaç eksikliği, diş sağlığı sigortası olmaması, uygun olmayan fiyat, ulaşım ve diş tedavisinden korkma diş hekimliği hizmetlerinin önündeki en yaygın önemli engeller olarak tespit edilmiştir (18). Paisi ve ark. (2020), sığınmacı ve mültecilerin ağı-diş sağlığı hizmetlerine erişimdeki karşılaştıkları engelleri belirlemeyi amaçlamışlar, bunun için literatür taramasından faydalanmışlardır, 9 makaleyi incelemeye almışlar ve mültecilerin ev sahibi ülkelerde ağız-diş sağlı̆̆ hizmetlerine erişimde ciddi zorluklarla karşılaştıklarını, bunlar arasında, satın alınabilirlik, iletişim güçlükleri, yetersiz iletişim, sağlık sistemleri ve hasta hakları hakkında sınırlı bilgiye sahip olmaları ve sağlık profesyonelleri ile olumsuz deneyimleri sayılmıştır. Özetle karşılanabilirlik, farkındalık, konaklama mülteciler tarafından en sık belirtilen engellerdir ve politika yapıcıların bunları göz önüne alması ve bu topluluklar için ağız-diş sağlığı hizmetlerine erişimi kolaylaştırmaları gerekmektedir (19).

Afshar ve ark. (2020), İran'ın Kerman kentindeki çocuk ve ergenlerin ağız ve diş sağlığına erişimlerini ve önündeki engelleri ebeveynlerinin bakış açısından değerlendirmeyi amaçlayan yazarlar, 245 ebeveyn üzerinde kesitsel bir çalışma yapmışladır. Demografik özellikleri, ebeveyn ve çocukların ağız-diş sağllğ 1 durumu hakkında bilgiyi, erişilebilirlik üzerine bilgiyi, erişimi iyileştirme hakkında görüşleri alan sorular olan anket uygulanmıştır. $\mathrm{Bu}$ çalışmada deneklerin \%28,6's1 erkek, geri kalanı kadındı. Çocukların ağız sağlığı durumu, katılımcıların \%37,6'sında orta düzeyde rapor edilmiştir. Erişimin önündeki en önemli engel $(\% 62,45)$ yüksek diş hekimliği maliyetleri iken, diş hekimliği hizmetlerini iyileştirmenin en sık yolu $(\% 35,1)$ çocuk dişlerinin bakımıyla ilgili eğitim olarak belirtilmiştir. Sonuçlara göre, ekonomik durum ile diş hekimine gelme zamanı arasında diş bakımına erişim engelleri arasında anlamlı bir ilişki tespit edilmiştir. Ayrıca, diş hekimliği hizmetlerine erişimi iyileştirmenin yolları ile ebeveynlerin eğitim düzeyi ile ağız sağlığı durumları arasında anlamlı bir ilişki gözlemlenmiştir. Özetle, bu çalışmanın sonuçlarına göre, diş bakımının önündeki en önemli engel yüksek maliyetler olmuştur. Ayrıca, çocuklara diş bakımı konusunda eğitim verilmesi, çocukların diş hekimliği 
hizmetlerine erişimini iyileştirmede en önemli faktör olarak belirlenmiştir (20).

Grafik 2- Ülkelere göre yapılmış çalışma sayısını göstermektedir. Ağız-diş sağlığı hizmetlerine erişim konusunda Web of Science'ta en fazla yayın ABD ülkeleri tarafından yapılmıştır.

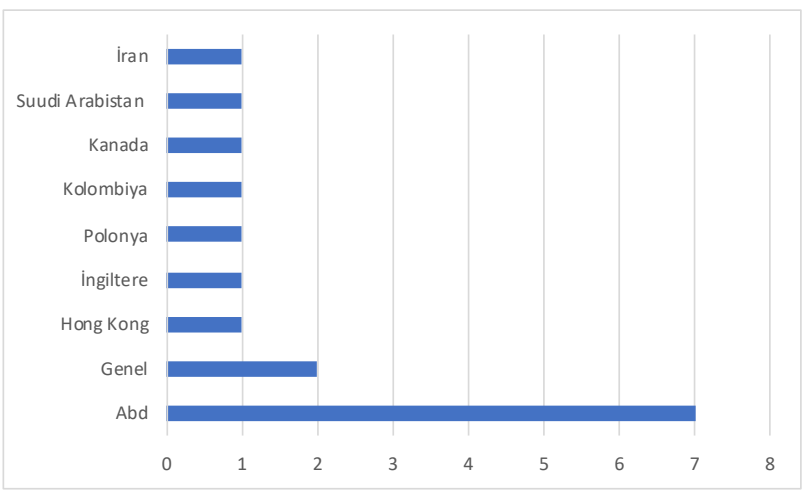

Grafik 2 - Ülkelere Göre Yapılmış Çalışma Sayısı

Web of Science taraması sonucu ulaşılan makalelerin genel sonuçları aşağıdaki Tablo-2'de verilmiştir.

Tablo 2 - Web of Science Çalışmaları Genel Sonuçları

\begin{tabular}{|c|c|c|c|c|}
\hline Yazar ve Yll & $\begin{array}{c}\text { Çalışmanın } \\
\text { Yapıldığı Ülke }\end{array}$ & Çalışmanın Amacı & Örneklem Grubu & $\begin{array}{l}\text { Ağız-Diş Sağlığı Hizmetlerine Erişimde Belirlenen } \\
\text { Engeller }\end{array}$ \\
\hline $\begin{array}{l}\text { O’Donnel } \\
\text { (1985) }\end{array}$ & Hong Kong & $\begin{array}{l}\text { Engelli bireylerin ağız diş } \\
\text { hizmetlerine erişim } \\
\text { engellerini belirlemek }\end{array}$ & Engelli Bireyler & $\begin{array}{c}\text { S1kışık barınma koşulları, aşırı kalabalık, engebeli } \\
\text { yollar, kapsayıcı sağlı sigortasının olmayışı, diş } \\
\text { hekimlerinin engelli bireyleri tedavi etmede isteksiz } \\
\text { olmaları }\end{array}$ \\
\hline $\begin{array}{c}\text { Freeman } \\
(1999,1999 b, \\
1999 c)\end{array}$ & Genel & $\begin{array}{l}\text { Ağı diş sağlı̆̆ hizmetlerine } \\
\text { erişimin önündeki engelleri } \\
\text { belirlemek }\end{array}$ & $\begin{array}{l}\text { Çocuklar, ergenler ve } \\
\text { yetişkinler }\end{array}$ & $\begin{array}{l}\text { Psiko-sosyal faktörler, dental kaygı durumları (dental } \\
\text { fobi), finansal maliyetler, ihtiyacın algılanması, erişim } \\
\text { eksikliği, dil ve iletişim bariyeri, özel ihtiyaçlı } \\
\text { bireylerin ihtiyaçlarının iyi tespit edilememesi }\end{array}$ \\
\hline $\begin{array}{l}\text { Mofidi vd. } \\
\text { (2002) }\end{array}$ & $\mathrm{ABD}$ & $\begin{array}{l}\text { Medicaid sigortalı çocukların } \\
\text { ağız diş sağlığı hizmetlerine } \\
\text { erişim sorunlarını belirlemek }\end{array}$ & Çocuklar & $\begin{array}{l}\text { Hizmet sağlayıcı bulamama, randevu alamama, } \\
\text { uygunsuz ve güvenli olmayan ulaşım, çok fazla } \\
\text { bekleme süresi, diş hekimleri ile negatif etkileşim, } \\
\text { Medicaid nedeniyle kötü ayrımcılık), deneyimin kalitesi } \\
\text { ile ilgili algılanan engeller, dil problemleri, rrksal } \\
\text { ayrımcılıklar, çocukların okul günü kayıpları, aileler } \\
\text { önüne koyulan sayısız engelden dolayı ailelerin } \\
\text { çocuklarını diş hekimine götürmekten vazgeçmeleri }\end{array}$ \\
\hline Guay (2004) & $\mathrm{ABD}$ & $\begin{array}{l}\text { Nüfus genelinin ağız diş } \\
\text { sağlığı hizmetlerine } \\
\text { erişimindeki engellerin } \\
\text { belirlenmesi }\end{array}$ & Nüfus geneli & $\begin{array}{c}\text { Yoksullar, kırsalda yaşayanlar, hareket kısıtlılığı olan } \\
\text { kişiler, kültürel olarak izole edilmiş kişiler, işsizler, } \\
\text { sigortasız olanlar, özel ihtiyaçları olan kişilerin hizmete } \\
\text { erişememesi }\end{array}$ \\
\hline $\begin{array}{l}\text { Schrimshaw } \\
\text { vd. (2011) }\end{array}$ & $\mathrm{ABD}$ & $\begin{array}{l}\text { Afroamerikalıların ağız diş } \\
\text { sağlığı hizmetlerine } \\
\text { erişimindeki engellerin } \\
\text { belirlenmesi }\end{array}$ & $\begin{array}{l}\text { New York'taki } \\
\text { Afroamerikalılar }\end{array}$ & $\begin{array}{l}\text { Afroamerikalıların teminat eksikliği, sigortasını kabul } \\
\text { eden bir diş hekimi bulamama, kapsamın yürürlüğe } \\
\text { girmesini beklemek, sigortasız veya eksik sigortası } \\
\text { olanların kalitesiz hizmet aldığı algısı }\end{array}$ \\
\hline $\begin{array}{l}\text { Bertolami } \\
\quad(2011)\end{array}$ & $\mathrm{ABD}$ & $\begin{array}{l}\text { Amerika'daki ağız diş sağlığı } \\
\text { hizmetlerine erişimin durum } \\
\text { tespiti }\end{array}$ & $\begin{array}{l}\text { Diş hekimleri ve diş } \\
\text { terapistleri }\end{array}$ & Artan nüfusa göre diş hekimi sayısının azlığ \\
\hline $\begin{array}{l}\text { Kalsi vd. } \\
\text { (2011) }\end{array}$ & İngiltere & $\begin{array}{c}\text { Londra'daki kalıtsal kanama } \\
\text { bozukluğu olan bireylerin ağız } \\
\text { diş sağlığı hizmetlerine erişim } \\
\text { zorlukları }\end{array}$ & $\begin{array}{l}\text { Londra' daki diş } \\
\text { hekimleri ve kalıtsal } \\
\text { kanama bozukluğu } \\
\text { olan bireyler }\end{array}$ & $\begin{array}{c}\text { Kalıtsal kanama bozukluğu (anemi) hastalarının yerel } \\
\text { bir diş hekimine ulaşamama, hastalıkları nedeniyle diş } \\
\text { hekimleri tarafından reddedilme, geçmiş deneyimler, } \\
\text { diş hekimlerinin ilgili bireylere hizmet verme hakkında } \\
\text { bilgi ve güven eksikliği }\end{array}$ \\
\hline $\begin{array}{l}\text { Thompson } \\
\text { vd. (2013) }\end{array}$ & Kanada & $\begin{array}{l}\text { Kanada'daki bireylerin ağız } \\
\text { diș sağlığı hizmetlerine } \\
\text { erişimindeki engellerin } \\
\text { belirlenmesi }\end{array}$ & Nüfus geneli & Hizmetlerin maliyeti, bireylerin geliri \\
\hline $\begin{array}{l}\text { Williams vd. } \\
\qquad(2015)\end{array}$ & $\mathrm{ABD}$ & $\begin{array}{l}\text { Diş hekimliği hizmetlerine } \\
\text { erişimdeki engellerin } \\
\text { belirlenmesi }\end{array}$ & $3-26$ yaş arası bireyler & $\begin{array}{c}\text { Özel ihtiyaçları olan kişilerin kendilerini tedavi etmeye } \\
\text { istekli diş hekimi bulamamaları, ankete katılanların } \\
\text { \%20'sinin diş hekimi olmadığını, düşük gelir, bekleme } \\
\text { süreleri, mesafe ve ulaşım }\end{array}$ \\
\hline $\begin{array}{l}\text { Gerreth ve } \\
\text { Borysewicz- } \\
\text { Lewicka, } \\
\text { (2016) }\end{array}$ & Polonya & $\begin{array}{l}\text { Zihinsel engelli özel bakım } \\
\text { okullarındaki çocukların ağız } \\
\text { diş sağlığ hizmetlerine } \\
\text { erişimlerindeki engellerin } \\
\text { belirlenmesi }\end{array}$ & Ebeveynler & $\begin{array}{l}\text { Bekleme süresi ve engelli çocukların hizmete } \\
\text { erişimindeki engeller }\end{array}$ \\
\hline $\begin{array}{c}\text { Higuera ve } \\
\text { Prada }(2016)\end{array}$ & Kolombiya & $\begin{array}{c}\text { Sağlık sigortasının ağız diş } \\
\text { sağlığı hizmetlerine erişimine } \\
\text { etkisi }\end{array}$ & $\begin{array}{l}\text { Sigortalı bireyler, } \\
\text { sigortasız bireyler }\end{array}$ & $\begin{array}{l}\text { Erişimde engel bulunamamış, maliyet paylaşımı çok iyi } \\
\text { yapılmaktaymış }\end{array}$ \\
\hline
\end{tabular}




\begin{tabular}{|c|c|c|c|c|}
\hline $\begin{array}{c}\text { Hamasha vd. } \\
\text { (2019) }\end{array}$ & Suudi Arabistan & $\begin{array}{l}\text { Yaşlı nüfusun ağız diş sağlığı } \\
\text { hizmetlerine erişimleri ve } \\
\text { yaşadıkları problemlerin } \\
\text { belirlenmesi }\end{array}$ & Yaşlı nüfus & $\begin{array}{c}\text { Algılanan ihtiyaç eksikliği, diş sağ lı̆̆ sigortası } \\
\text { olmaması, uygun olmayan fiyat, ulaşım ve diş } \\
\text { tedavisinden korkma }\end{array}$ \\
\hline $\begin{array}{l}\text { Paisi vd. } \\
(2020)\end{array}$ & Genel & $\begin{array}{l}\text { Sığınmacı ve mültecilerin ağız } \\
\text { diş sağlığı hizmetlerine } \\
\text { erişimde yaşadıkları } \\
\text { problemlerin belirlenmesi }\end{array}$ & Literatür & $\begin{array}{l}\text { Sığınmacı ve mültecilerin bildirdiği; satın alınabilirlik, } \\
\text { iletişim güçlükleri, yetersiz iletişim, sağlık sistemleri ve } \\
\text { hasta hakları hakkında sınırlı bilgiye sahip olmaları ve } \\
\text { sağlık profesyonelleri ile olumsuz deneyimler }\end{array}$ \\
\hline $\begin{array}{c}\text { Afshar vd. } \\
(2020)\end{array}$ & İran & $\begin{array}{l}\text { Çocuk ve ergenlerin ağı diş } \\
\text { sağlığı hizmetlerine } \\
\text { erişimlerinin önündeki } \\
\text { engelleri ebeveyn bakış açısı } \\
\text { ile değerlendirmek }\end{array}$ & Ebeveynler & Yüksek maliyetler \\
\hline
\end{tabular}

Grafik 3 ağız-diş sağlı̆̆ hizmetlerine erişimde en çok bildirilen engelleri göstermektedir. Buna göre yapılan çalışmalarda en çok bildirilen engel; diş hekimlerinin isteksiz davranışları, hizmetlerin maliyeti ve özel hizmet ihtiyacı olan bireylerle ilgili engellerdir. Daha sonra sırasıyla; sigorta ile ilgili engeller, ulaşım, hizmet sağlayıcı bulamama, uzun bekleme süreleri, kalitesiz hizmet algısı, gelir düşüklüğü diye devam etmektedir.

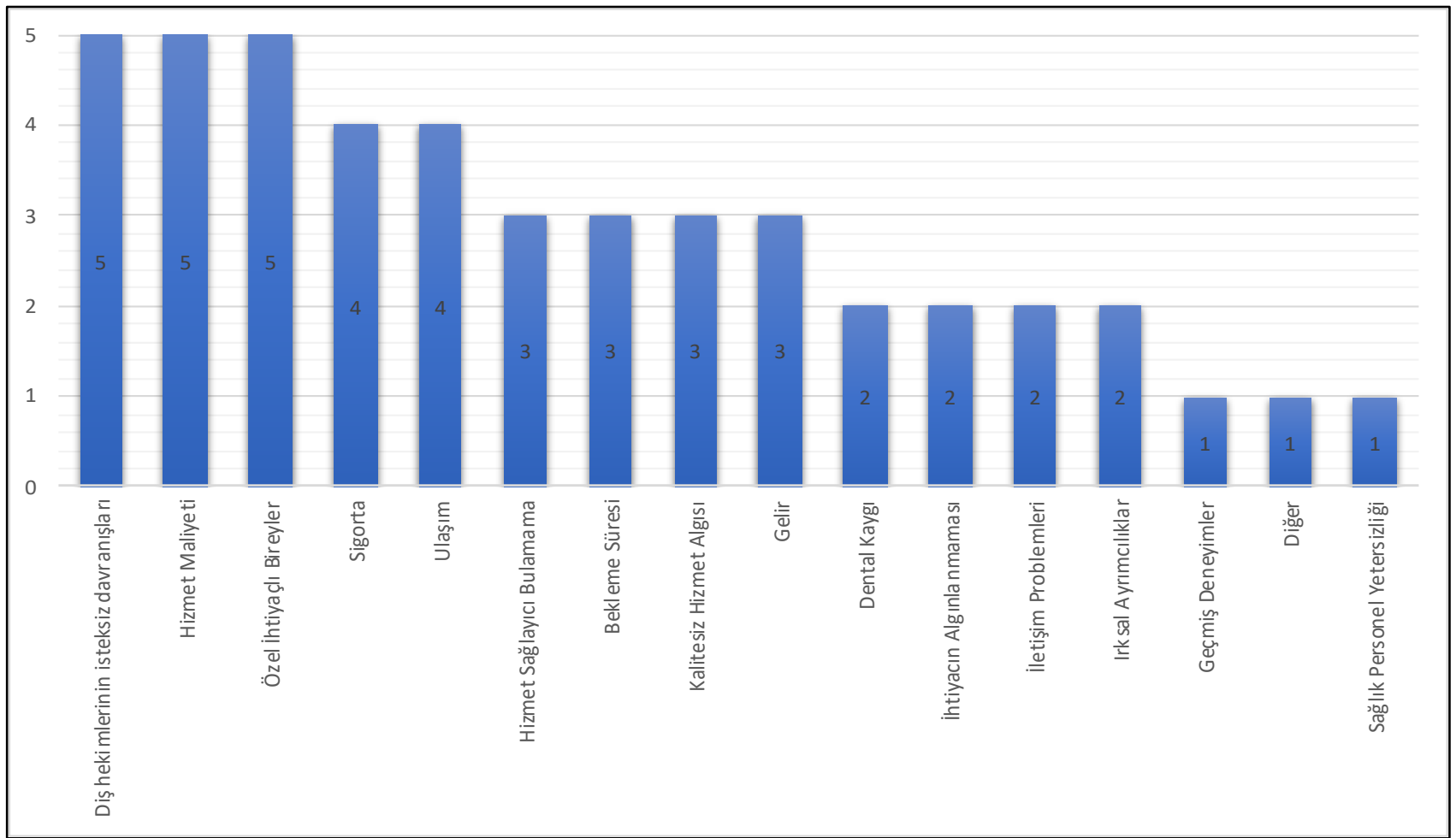

Grafik 3 - En Çok Bildirilen Engeller

\section{Tartıșma}

Çalışma kapsamında incelenen makalelerin çoğunun ( $\mathrm{n}=7, \% 43)$

ABD'de yapıldığı, en sık belirtilen engellerin; diş hekimlerinin isteksiz davranışları $(n=5, \% 10,8)$, hizmetlerin maliyeti ve özel hizmet ihtiyacı olan bireylerle ilgili engeller olduğu, daha sonra sırasıyla; sigorta ile ilgili engeller, ulaşım, hizmet sağlayıcı bulamama, uzun bekleme süreleri, kalitesiz hizmet algis1, gelir düşüklüğü, dental kayg1, ihtiyacın algılanamaması, iletişim problemleri, ırksal ayrımcılıklar, geçmiş deneyimler ve sağlık personelinin eksikliği engellerinin geldiği tespit edilmiştir.
Literatürdeki derleme çalışmalarında ağız-diş sağlığı hizmetlerine erişimdeki engellere belli grupların bakış açısı ile bakıldığı ancak yine de mevcut derleme çalışmalarında grup bazında elde edilen sonuçların bu çalışmanın sonuçları ile paralel olduğu söylenebilir.

\section{Sonuç ve Öneriler}

Sonuç olarak ister çocuklar, ergenler, yetişkinler, yaşlı nüfus, engelli bireyler veya ister diş hekimleri ile yapılan çalışmalar olsun, ortak varılan sonuç ağız ve diş hekimliği hizmetlerine erişimde engeller yaşandığ 1 , bu engellerin ülke ve incelenen 
gruplara göre çeşitlilik göstermekle beraber genel olarak en fazla etkilenen grupların engelli bireyler, yoksullar, özel bakım gereksinimi olan bireyler, kırsalda yaşayanlar, yaşlı bireyler ve çocuklar olduğu görülmüştür.

Çalışmaların yapıldığı ülke ayırt etmeksizin neredeyse tüm ülkelerde (sadece yapılan tek bir çalışma Kolombiya'da bu hizmetlere herhangi bir erişim engeli olmadığını belirtmiştir) (17) ağız ve diş sağlığı hizmetlerine erişimde engeller yaşandığı ve bunun çözümünün sadece tek bir konuya çözüm getirerek kalıc1 olamayacağını görebilmekteyiz.

Çözüm önerileri olarak, toplumda ağız-diş sağlığı hizmetlerine erişimde engeller yaşayan kesimler olduğunun bilincinde olarak hükümetlerin bu engelleri en aza indirecek sağlık politikaları oluşturmaları, sağlık sigorta kapsamlarının en azından dezavantajlı bireyler için yükseltilmesi, hizmet sunum kurumlarının coğrafi dağılımının erişimi engellemeyecek şekilde planlanması, diş hekimlerine ve ağız-diş sağlı̆̆ı sağlık profesyonellerine özel hizmet gereksinimi olan bireyler ve bunlara nasıl yaklaşılması, nasıl tedavi verilmesini içerecek kurs/eğitimlerin verilmesi önerilebilir.

Ayrıca engelli kişilerin ağız diş sağlığı hizmetlerine erişimde karmaşık fiziksel, davranışsal veya çok boyutlu engellerle karşılaşmaya devam ettiği, bu grupta yer alan bireylerin bakımı için diş hekimlerinin iyileştirilmiş (güncelleştirilmiş) eğitim almaları gerektiği, engellilerin ağız-diş sağlığı hizmetlerine erişimini sağlayan yasal çerçevelerin oluşturulmasının önemli olduğu göz ardı edilmemelidir (5).

Çıkar Çatışması: Çalışmada herhangi bir çıkar çatışması yoktur.

Finansal Destek: $\mathrm{Bu}$ makalede herhangi bir finansal destek alınmamıştır.

Etik Kurul Onayı: Bu makale derleme türünde yazıldığı için etik kurul onayına gerek yoktur.

\section{Kaynaklar}

1. Freeman R. Barriers To Accessing and Accepting Dental Care. British Dental Journal. 1999;187(2):81-84

2. El-Yousfi S, Jones K, White S, Marshman Z. A Rapid Review of Barriers to Oral Healthcare for Vulnerable People. British Dental Journal. 2019;227(2):143-151.

3. Goode J, Hoang H, Crocombe L. Homeless Adults' Access to Dental Services and Strategies to Improve Their Oral Health: A Systematic Literature Review. Australian Journal of Primary Health. 2018,24:287-298.

4. Hadgkiss EJ, Renzaho AMN. The Physical Health Status, Service Utilisation And Barriers to Accessing Care for Asylum Seekers Residing in The Community: A Systematic Review of The Literature. Australian Health Review.2014;38:142-159.
5. Rosa SV, Moynes SJ, Theis L, Soares RC, Moyses S, Werneck RI, et al. Barriers in Access to Dental Services Hindering the Treatment of People with Disabilities: A Systematic Review. International Journal of Dentistry. 2020:1-17.

6. O'Donnell D. Handicapped People in Hong Kong: The Problems of Access to Dental Care. Journal of The Royal Society of Health. 1985;105(4):141-143.

7. Freeman R. Barriers To Accessing Dental Care: Patient Factors. British Dental Journal. 1999b;187(3):141-144.

8. Freeman R. Barriers To Accessing Dental Care: Dental Health Professional Factors. British Dental Journal. 1999c;187(4):197-200.

9. Mofidi M, Roizer G, King RS. Problems With Access to Dental Care for Medicaid-Insured Children: What Caregivers Think. American Journal of Public Health. 2002;92(1):53-58.

10. Guay A. Access to Dental Care Solving The Problem For Underserved Populations. Journal of The American Dental Association. 2004;135:1599-1605.

11. Schrimshaw EW, Siegel K, Wolfson NH, Mitchell DA, Kunzel C. InsuranceRelated Barriers to Accessing Dental Care Among African American Adults With Oral Health Symptoms in Harlem, New York City. American Journal of Public Health. 2011;101(8):1420-1428.

12. Bertolami CN. Access to Dental Care: Is There a Problem? American Journal of Public Health. 2011;101(10):1817.

13. Kalsi H, Nanayakkara L, Pasi KJ, Bowles L, Hart DP. Access to Primary Dental Care For Patients With Inherited Bleeding Disorders. Haemophilia. 2011:1-6.

14. Thompson B, Cooney P, Lawrence H, Ravaghi V, Quinonez C. Cost as a Barrier to Accessing Dental Care: Findings From a Canadian Population-Based Study. Journal of Public Health Dentistry. 2014;74:210-218.

15. Williams JJ, Spangler CC, Yusaf NK. Barriers to Dental Care Access For Patients With Special Needs in an Affluent Metropolitan Community. Special Care Dentistry Association and Wiley Periodicals. 2015;35(4):190-196.

16. Gerreth K, Borysewicz-Lewicka M. Access Barriers to Dental Health Care in Children with Disability. A Questionnaire Study of Parents. Journal of Applied Research in Intellectual Disabilities. 2016;29:139-145.

17. Higuera, L, Prada SI. Barrier to Access or Cost Share? Coinsurance and DentalCare Utilization in Colombia. Applied Health Econoiıcs And Health Policy. 2016;14(5):569-578.

18. Hamasha AA, Aldosan MN, Alturki AM, Aljohani SA, Aljabani IF, Alotibi RF. Barrier To Access And Dental Care Utilization Behavior With Related İndependent Variables in The Elderly Population of Saudi Arabia. Journal of International Society of Preventive \& Community Dentistry. 2019;9(4):349-355.

19. Paisi, M, Baines R, Burns L, Plessas A, Radford P, Shawe J, at al. Barriers And Facilitators to Dental Care Access Among Asylum Seekers And Refugees in Highly Developed Countries: A Systematic Review. BMC Oral Health. 2020;20(1):1-10. 20. Afshar MK, Tahmorsi M, Torabi M, Taher, A, Mohammadzadeh I. Barriers And Access to Oral-Dental Care Among Children And Adolescents in Kerman, Iran. An Evaluation Of Parents' Viewpoints. International Journal Of Medical Dentistry. 2020;24(4):560-567 